\title{
Young Women and Feminised Work: Complicating Narratives of Empowerment through Entrepreneurship with the Stories of Coffeehouse Owners in Wukro, Ethiopia
}

\section{Zoë Johnson}

\begin{abstract}
Development narratives posit that, through entrepreneurship, young women can become empowered economic agents, instrumental to the development of their communities. As feminist scholars have pointed out, these narratives serve to homogenise, depoliticise, and ahistoricise the category of 'young woman' and to naturalise the inequitable global structures in which it is embedded. To universalise young womanhood is to ignore the ways in which young women's lives are shaped by their cultural contexts and by structural constraints. As a result, most development schemes targeting young women as entrepreneurs fail to recognise the ways in which engaging in entrepreneurship can reinforce rather than break down gendered differences and vulnerabilities. Using life herstory methods grounded in feminist methodologies, this article tells the stories of young women coffeehouse owners in Wukro, Ethiopia, revealing some of the often-overlooked sociocultural issues facing young women entrepreneurs in development contexts. It argues that putting young women at the centre of policy-making processes is a crucial starting point for promoting inclusive and transformative development.
\end{abstract} Keywords: life herstories, young women, empowerment, entrepreneurship, feminisation

Johnson, Zoë. 2020. 'Young Women and Feminised Work: Complicating Narratives of Empowerment through Entrepreneurship with the Stories of Coffeehouse Owners in Wukro, Ethiopia.' Gender a výzkum / Gender and Research 21 (1): 64-88, http://dx.doi. org/10.13060/gav.2020.004.

Bunabéts (coffeehouses) abound in Ethiopian cities. In Wukro, a small city in the Tigray region of Ethiopia, darkened doorways on every street beckon drinkers into dim rooms hung with posters of beaming women perched behind rekobot (low tables used to serve coffee), or plastered with motivational quotes from characters as varied as Albert Einstein, Bob Marley, Gandhi, Jesus, and Meles Zenawi (the late Prime Minister 
of Ethiopia, a much loved character in Tigray). In Wukro, coffeehouses are not the 'modern' macchiato-serving cafés that have become common in larger cities such as Addis Ababa; rather, these small-scale establishments brew coffee in a jebena (a bulbous terracotta pot) over a charcoal fire and serve it in small handle-less demitasse cups. It is prepared in a ceremony which involves roasting the beans over charcoal and fanning their smoke about so everyone can enjoy the smell, and then serving the coffee alongside burning frankincense and myrrh. The performance of the ceremony is highly gendered, symbolising feminised characteristics of hospitality, skill, and hard work.

Coffeehouses in Wukro serve important social, economic, and cultural functions for the communities which frequent them and for the young women who run them. Because in Tigray coffee is always prepared by women, and because of the gendered perceptions around what it means to run a bunabét, these businesses are owned exclusively by young, unmarried women entrepreneurs. In other words, owning a bunabét is a specifically feminised form of work. There has been an explosion in the number of bunabéts in Wukro over the last decade, coinciding with a period of rapid economic growth, urbanisation, and political and social change in the country. Bunabéts are spaces reflective of this dynamic period in Ethiopian herstory, in which meanings associated with the discursively constructed category 'young woman' are being (re)shaped. How are the young women of Wukro's bunabéts making sense of their circumstances and contending with the dynamic discourses shaping their place in society and in Ethiopia's development nexus?

In development programmes in Ethiopia (and across the Global South), efforts are being made to ensure the inclusion of women - and young women in particular. Adolescent girls have been heralded as the key to economic development in the Global South (Switzer 2013). Narratives around young women posit that through entrepreneurship, as one mechanism among many, young women can become empowered economic agents. Despite the policy attention they receive, however, young women themselves tend to remain 'silent figures', merely the subjects of wellintentioned development schemes (Kirk, Mitchell, Reid-Walsh 2010). As a result, many development programmes fail to recognise the ways in which entrepreneurship can exacerbate women's vulnerabilities and reinforce their social positioning.

By sharing the stories of young women entrepreneurs in Wukro, this research aims to add to the increasingly textured accounts of young women's lives emerging from literatures on feminist development, girlhood, and youth. 'Through these stories,

The field costs for this research were covered by the REACH programme (www.reachwater.org. uk), funded by UK Aid from the UK Department for International Development (DFID) for the benefit of developing countries (Aries Code 201880). However, the views expressed, and the information contained in it are not necessarily those of or endorsed by DFID, which can accept no responsibility for such views or information or for any reliance placed on them. 
this work seeks to challenge and complicate development narratives that assign young women narrow essentialised subject-positions as "key "instruments" for alleviating poverty, slowing population increase, and generating economic growth' (Moeller 2014: 581), and to counter the homogenisation and universalisation of the ways that young women impact, and are impacted by, development. By reflecting on how young women in Wukro are reacting to and reshaping the ever-changing discourses surrounding their lives, this research reveals some of the often-overlooked sociocultural issues facing young women entrepreneurs in development contexts. I argue that putting young women themselves at the centre of policy-making processes is a crucial starting point for promoting inclusive and transformative development, especially if we plan to target young women as important development actors.

\section{Women and girls in international development discourse}

The mainstreaming of gender in development policy began as early as the 1980s, when research, much of it commissioned by large international development agencies, began documenting the 'development potential' of women in the Global South. Much of this research claims that women work more efficiently, invest more of their income into their families, and are better at paying back loans compared to men (Shain 2012). These feminist development 'fables' (Cornwall, Harrison, Whitehead 2008) are the result of a convergence of liberal development and liberal feminism (Moeller 2014; Shain 2012), and have created what Roy calls the 'feminization of policy' (Roy 2010: 70).

Feminist, post-colonialist, and Marxist development scholars have problematised mainstream development's approach to 'women's empowerment', because even when promoting non-traditional paths such as entrepreneurship, they are founded on instrumental notions of 'empowerment' and frequently fail to challenge the broader structural and sociocultural issues facing girls and women (Moeller 2014). 'Empowerment' schemes tend to rely on anaemic, essentialised depictions of women as 'hard working, peaceful, caring, altruistic and inherently virtuous... [They] peddle gender myths that sustain an image of the "good woman" as the deserving object of development assistance' (Cornwall, Anyidoho 2010: 145). Empowerment in this context has lost much of its meaning, becoming among the most elastic of international development's many buzzwords (along with agency, a concept to which it is intimately connected) (Cornwall 2007). Whereas 'empowerment' was once used by radical feminists seeking to transform unjust and unequal power relations, it has become a term used by an expansive discourse coalition of corporations, global non-governmental organisations, banks, philanthrocapitalists, and development 
donors. In the process, many insights from feminist conceptual work have been lost (Cornwall 2016).

Young women in particular have been portrayed in these neoliberal development models as 'economic agents of change' (Anyidoho et al. 2012: 7). In his 2008 speech, made at the launch of the Adolescent Girls Initiative (a public private partnership between the World Bank, the Nike Foundation, and some European governments), Bank President Robert Zoellick said: 'Investing in adolescent girls is precisely the catalyst poor countries need to break intergenerational poverty and to create a better distribution of income. Investing in them is not only fair, it is a smart economic move.' (World Bank 2008). His comments reflect the explosion of policy and development interest in 'empowering' adolescent girls as a means of reducing poverty, population growth, the spread of HIVIAIDS, and improving economic growth and the conservation of environmental resources (Moeller 2014). This model is predicated on the 'rescue and the regulation of adolescent female bodies by distant saviours from the tourniquet of local tradition' (Switzer 2013: 351). The idea is that by pushing back the timing of childbearing and marriage, it becomes possible to unleash girls' economic potential (Moeller 2014).

The categorisation of young womanhood that emerged from this development narrative has served to reshape what it means to be a young woman in the Global South so that they fit within the emerging (neo-liberalised) social and global economic order (McRobbie 2009). Through this process, adolescence has been portrayed as a universal moment of human development, when in reality it is a cultural construct (Helgren, Voscancellos 2010). To universalise young womanhood in this way is to ignore the very real ways in which young women's lives are shaped by their cultural contexts and the constraints of the conditions in which they live. As a result, most development schemes targeting young women as entrepreneurs fail to recognise the ways in which engaging in entrepreneurship - while perhaps expanding certain economic possibilities - also makes young women vulnerable to an array of discourses that serve to discipline them in both symbolic and material ways. As Switzer (2013: 347) argues, this discourse 'makes invisible the sometimes violent and coercive appropriations of (young) female sexualised bodies' within purportedly 'safe spaces' such as work, as the stories below will illustrate.

Despite all the attention they receive, researchers have argued there has yet to be a 'sustained scholarly dialogue' about girlhood in the Global South (Kirk, Mitchell, Reid-Walsh 2010: 20-21). Until recently, the majority of studies on childhood and youth accepted the experiences of boys as normative (Helgren, Vasconcellos 2010). Most scholarship in the growing field of youth in development acknowledges the gendered dimensions of youth as a category, but, generally, it is addressed briefly and superficially with a paragraph or so devoted to outlining the fact that young women 
experience the transition between childhood and adulthood differently than young men, or pointing out the differences between markers of adulthood for women and men. Many authors fall short of offering concrete empirical material that would allow them to flesh out the lived realities of being a young woman. ${ }^{2}$

The problems associated with the exclusion of young women's experiences in the formulation of the category 'youth' extends into policy. Both the African Youth Charter (AUC 2006) and Ethiopian National Youth Policy (FDRE-MoYSC 2004) mention the importance of gender equality in youth policy; however, this does not change the fundamental male bias behind the formulation of the category at the core of these policies. The way 'youth' is used throughout both documents remains, on the whole, gendered. In the National Youth Policy in particular, the emphasis on women's vulnerability in terms of early marriage, early childbearing, unintended pregnancies, and sexually transmitted infections speaks to a continuation of longstanding discursive constructions of young women's victimisation and transgressions in the narrow terms of sex and marriage. As Waller (2006: 83) describes, in colonial Africa, 'male deviants were stigmatised as idle, potentially violent, and possibly criminal', while 'their female counterparts were simply "loose"', evidencing the fact that "'girls" behaving badly in non-sexual ways' have been rendered largely invisible. These representations undermine the importance of challenges in other dimensions of young women's lives such as employment. In Ethiopia, like elsewhere, women's exclusion has serious policy implications. Young women very often fall through the cracks that exist between agendas on children's rights, youth rights, and women's rights (Aling'o, Abdulmelik 2017).

\section{Young women in Ethiopian development}

Women have been a longstanding focus of Ethiopian development efforts and have played an important (though often overlooked) role in Ethiopian herstory. When the Ethiopian People's Revolutionary Democratic Front gained power in 1991, they recognised the importance of including women in their development plans. In 1993, a National Policy of Women was introduced with the aim of achieving greater equality for women (FDRE-MoWCA 1998). Since then, an increasing emphasis on education

\footnotetext{
2 Of course, there are a few notable exceptions to this trend. Using data from a longitudinal study conducted by Young Lives, Camfield and Tafere (2011) explore adult perspectives on childhood transitions in Ethiopia, arguing that transitions are rarely linear. Utas (2005) analyses the experiences of young women in the Liberian civil war, and Enria (2018) includes the voices of young women in her book on the relationship between labour market experiences and the pattern of social mobilisation among young people in a post-conflict Sierra Leone.
} 
(for both boys and girls), coupled with a trend towards later marriage - a consequence of urbanisation, unemployment (Gebre-Egziabher, Yemeru 2019), and efforts by the Government of Ethiopia (GoE) and the international community to reduce the prevalence of child brides (Mengistu 2017) - changed the opportunities available to young women in urban centres. Recent events have drawn renewed attention to this trend: in 2018, Ethiopia's new Prime Minister, Abiy Ahmed, put together the first cabinet with gender parity and made historic appointments of women to highprofile positions, such as the presidency and supreme court. While these may be little more than cosmetic changes, the elevation of women to such visible posts has served to highlight the slowly shifting meaning of the discursive category 'woman' in the Ethiopian context.

Youth, too, have been a concern for Ethiopian leaders over the last six decades. This is not surprising given the central role that youth have played in political and social change over the course of the country's herstory. In Ethiopia, as in much of the rest of the world, the category 'youth' has been deployed both to stigmatise and control people through an assertion of incomplete personhood, as well as to 'empower' and emancipate those who fall within its bounds (Burgess, Burton 2010; Waller 2006). Over time, youth have occupied various subject positions within Ethiopian national discourses, in which they have been portrayed both as 'future leaders' responsible for the development and 'modernisation' of Ethiopia (Balsvik 1998) and as violent 'vagrants' who pose an existential threat to the country (Gebremariam 2017). Since 1991, unemployment has shaped narratives around youth, who have borne the brunt of the country's unemployment problem (Broussard, Tekleselassie 2012). Despite the unprecedented recent increase in gross domestic product, unemployment rates for urban youth remain quite high, especially for women (Rekiso 2019), whose opportunities in smaller cities are largely limited to entrepreneurial activities (Oya 2019). Entrepreneurship through micro and small-scale enterprises ${ }^{3}$ (MSEs) is an important mechanism through which the GoE purports to 'empower' young women. This is reflective of the global trend described above.

Interestingly, there is a contradiction at the heart of the GoE's promotion of young women's entrepreneurship through MSEs. Most MSEs in Ethiopia, particularly those run by women (bunabéts included), exist in the 'informal' sector, which according to the GoE's 2009 National Employment Policy and Strategy of Ethiopia, is characterised by underemployment, poor earnings, and a lack of institutional protections (FDREMoLSA 2009). Therefore, the focus on MSEs as a viable route to success for young women seems to contradict the simultaneous portrayal of the 'informal' sector as an

3 According to the GoE definition, service sector MSEs are 'enterprises employing a maximum of five persons... with a total asset of not more than ETB 50,000 [f1,300]' (FDRE-MoUDH 2012: 19). 
inherently undesirable space (Broussard, Tekleselassie 2012). As the stories below will illustrate, these contradictory representations of women's work in the informal sector can be used instrumentally by patriarchal powers to place the burden of development on women or to undermine the legitimacy of women's entrepreneurship when it impinges on society's feminine ideals (Cornwall, Anyidoho 2010).

This contradiction extends into global development discourses around young women's un(der)employment as well. There is often a focus placed by policymakers and development professionals on 'entrepreneurship as the best (and only) response to the youth employment challenge' and a vehicle for youth and women's empowerment; while at the same time, these discourses operate on the implicit (or explicit) assumption that 'wage employment in the formal sector is the gold standard, while everything else is simply work, or 'waiting' (Ayele, Khan, Sumberg 2017: 4). While not all of the women I spoke with were directly involved in programmes promoting MSEs or entrepreneurship (though some had been), the prevalence of these discourses has in part made it possible for young women to operate such businesses, and the tensions embedded within the discourses that simultaneously promote self-employment and discredit the informal sector are reflected in the ways women describe their perception of work in bunabéts.

\section{Feminist life herstories}

I interviewed a total of thirty coffeehouse owners around the city of Wukro between June and August 2018. ${ }^{4}$ I used life herstory methods grounded in feminist methodologies. All of the interviews were conducted in Tigrinya with the help of my interpreter, who was a graduate student living in a nearby city. I conducted multiple interviews with six of the thirty interviewees and fostered particularly strong relationships with three key informants in whose coffeehouses I spent countless hours. These are the women whose stories I share in this article. Each story serves to showcase a different though reoccurring set of experiences described in various manifestations by all thirty of my informants. My analysis is rounded out using data collected through participant observation, life herstory interviews with other community members in Wurko (19 in total), and semi-structured interviews with 'officials', including from the city administration, municipal and regional water utility offices, micro-finance institutions, and UNICEF.

4 This research was undertaken as part of a larger project with the REACH project, a global research programme building evidence for the connections between water security and poverty in Eastern Africa and South Asia and was part of my master's thesis project. It was done with approval from the Central University Research Ethics Committee (CUREC) at the University of Oxford. Permissions were also granted from the Wukro City Administration, and oral consent was obtained from all participants. 
Using life herstory methods serves to give narrators control over their own stories, which is conducive to the feminist underpinnings of this work because it legitimates women's narratives (as told by women themselves) as valuable sources of knowledge (Campbell, Wasco 2000). Furthermore, development narratives posit that entrepreneurship is a viable path by which youth and women can become 'empowered.' To me, 'empowerment' involves young women thinking differently about themselves, 'about the situations they are in, about their social worlds, relationships and horizons' (Cornwall 2016: 356). For that reason, it is important to work 'at the level of individual consciousness' to understand young women's 'sense of their own possibilities' and gain a critical understanding of the societal dimensions of the obstacles they currently face (Cornwall 2016: 356). Life herstories produce knowledge that is polyphonic, containing multiple perspectives, truths, and meanings (Etherington 2006). Perhaps it would be more appropriate to call this method 'life story', since that does not 'connote that the narration is true, that the events narrated necessarily happened, or that it matters whether they did or not' (Peacock, Holland 1993: 368). I have chosen instead to use 'life herstory' in an attempt to emphasise the feminist foundations of this research and to disrupt normative masculine assumptions about narrations of the past.

In part because both I and my interpreter were young women and the coffeehouse owners were also young women, we were able to build trusting, friendly relationships, and many of our interviewees were very open in sharing their life stories. Additionally, the sociable atmosphere of the coffeehouses in Wukro provided a perfect backdrop for conversations. While as a ferenji (foreigner) my presence rarely went unnoticed, taking part in the culture of coffee drinking gave me a point of entry into conversations. Despite the importance that our shared gender and age played in shaping this research with coffeehouse owners in Wukro, I do not presume that these elements of our common identity overrode our many differences, and the power dynamics that these differences entail.

Confronting the power differential that exists between actors in the context of qualitative interviews is a cornerstone of feminist methodological approaches (van Stapele 2014). In line with feminist methodology - and in an attempt to undermine the 'researcher-researched' disconnect created by the institutional affiliation, young age, and gender of both my interpreter and myself, as well as my white skin - I approached the interviews in a minimally structured way using openended questions and probing topics raised by the interviewee herself. My aim was to avoid imposing my ideas about what is important in the lives of the interviewees, to let the explanations and interpretations provided by my participants about their own lives become the data I analysed (Glaser, Strauss 1967). Nonetheless, I recognise that no matter how open-ended, there are no neutral questions. As a researcher, 


\section{STATI / ARTICLES}

my agenda was asserted through the questions that I asked and the way that I framed my research to participants, which ultimately propelled the narrative along a particular course (Hoppe 1993). The act of conducting research is itself an example of academic performance, and my presence played a role in shaping the performances of my interlocutors (Gregson, Rose 2000). For this reason, throughout both data collection and analysis, I gave careful consideration to how questions and actions were understood by my interviewees, and how I interpreted their answers (Hoppe 1993).

Most interviews were not recorded but were documented with extensive written notes. Devault (1990) discusses strategies that do not involve recording, which can be used by feminist researchers to create meaningful representations of women's speech. During early interviews, I noticed that the recording device invoked nervousness and limited the depth of participants' responses. As a result, I moved towards careful descriptive notes on the interview surroundings and documentation of the timing and the general format of the interviews. I took notes during the interview and then, immediately afterward, worked with my interpreter to record a detailed process account of everything that was said. For example, I recorded 'dialogue accessories', such as gesture and tone, in my notes to help remember the conversations (Devault 1990: 106). My interpreter's translations went beyond simply the words that were spoken as she helped me to understand the cultural significance and social meaning of some of the respondents' comments. In this way, she also became an informant by providing information about the social world that I was investigating (Edwards 1998).

Conducting interviews without recording does have limitations: the inevitability of 'selective recall' increases the power of the researcher to decide (even if subconsciously) which parts of the interviewees' stories are included in the written text (Bhopal 2010). This dynamic was mitigated slightly by the fact that both my interpreter and I participated in the interviews and then collaboratively engaged in their reconstitution after the fact. Furthermore, the format of the interviews with coffeehouse owners - given the open-ended nature of the questioning and the fact that we were most often interviewing the women while they were working - made recording difficult. The method I chose was therefore suited to the circumstances of my fieldwork, the types of data analysis I used, and the nature of the claims I make.

Just as every informant is interminably complex and unique, there are infinite ways in which their stories could be told and theorised. I chose to bring these narratives together based on the elements of their retelling that I deemed important and compelling within the analytical perspective that I have described. I argue that these representations are important if we hope to include young women in the 
process of development. Only by looking at young women's lived experiences of development can we begin to unravel the complex shifts these changes are causing to their perceptions of possibility and constraint. These understandings can, in turn, help inform better policy through which we can work toward inclusive development.

\section{Tigisti: 'Being serious' about your work}

I grew up in a rural area. It was near Adigrat [a city in north-eastern Tigray]. I left school in Grade 11 because I ran away to Wurkro. I stole money from my parents to pay for the transit to Wukro... They wanted me to get married. They were very angry [when I left] ... I really liked school, but I had to leave because I didn't want to get married (I was 17). After you get married you are just stuck at home. Now all of my friends are married and have two, three children. Once you're married you are destined to be tied to household activities. You are not free to do business and to own your own things ... Women in the rural areas do not own businesses. Sometimes they are shopkeepers, but it is their families' business, not their own.

When I got to Wukro, I worked as a waitress before I opened my bunabét. At that time Wukro was a very good place to do this business because there were many meetings. I used money I had saved while working to open my business. My father also borrowed some money to help me.

Now, I often send money to my parents. . They were very upset when I left, but now they are happy - but somehow, they are also not happy because they think that what I am doing is difficult. At this age, I could just be living on what my husband brings home. I woudn't have to toil here. I wouldn't have to worry about the rent, business, profit, costs. . This business is very difficult because the costs are high. Glasses are always being broken. I have to pay for the girls [employees], pay for their food. I also need to buy four packs of charcoal per month because I need it to continue serving tea and coffee whenever the power goes out.

I don't think it's good to be friends with other girls who own bunabéts because if you do, you will no longer be serious about your business. They might want you to hang out, go to clubs, and this will not help you to focus much on your work. They are not serious about their work. They just hire some girls and then they leave all the work to the waitress or the other girls. Many of the 
coffeehouse girls who opened businesses with me [at the same time] are no longer doing it. Also, those who started after me, you won't find them there now. They are not running a bunabét any longer, because it is very difficult to own this business. After they close their coffeehouses, they get married. Many got married to their customers. . I won't get married until after I open a supermarket.

Once you get married, your husband won't let you run this business because he will think you are cheating on him and going out with other men. [If you are married] people [customers] won't come to your bunabét because they don't feel comfortable or free to have fun if your husband is here. You have to drink and enjoy [yourself] with people, so this business and marriage cannot go together.

Everyone in Wukro thinks that if you open a coffeehouse, it is because you're doing the 'other business' [prostitution]. There are some [who actually do this work], but I don't know the number. It is only the men who are talking about it. [Men] sometimes ask [to spend the night], but how you respond depends on your strength. You have to be polite and nice to them, but when it is things that matter to your life, you have to say 'no'. Even sometimes when you need that [money], you have to say 'no' for the sake of your work, for the sake of what you are doing. What matters is the way you respond to what they say. It is up to you to decide whether you will be doing what they tell you or not. If they want you to serve them, then you do your best because it is your work, but when it get personal you have to be very assertive, you have to be strong. Some people appreciate when you are serious about your work and refuse to go out with one guy and another guy. They will appreciate you and they will continue to be your customers. Others will not come back to you after you say 'no' to them. ${ }^{5}$

Entrepreneurship has been portrayed as a way that 'people can change the meaning of gender and the way in which gender is lived' (Hanson 2009: 245), and it has been argued that entrepreneurship creates employment opportunities, fosters resilience, and increases young people's social and cultural identities, bringing marginalised youths into the mainstream of economic activities (Chigunta et al. 2005). Therefore, starting a small business should expand young women's possibilities for upward

5 All quotes from Tigisti were collected during interviews conducted in her coffeehouse in Wukro on 3 and 8 August 2018. 
socioeconomic mobility. As Tigisti's ${ }^{6}$ story demonstrates, there are some ways in which these narratives hold true; however, her story also provides evidence for the ways in which, by engaging in entrepreneurship, young women perceive themselves to be subjected to different types of disciplining discourses that constrain them in different ways. These discourses are grounded in age-old tropes about the threat of female independence and sexual promiscuity. Entrepreneurship in this context thus serves to preserve the 'meaning of gender' and the 'way in which gender is lived'. Furthermore, rather than bringing young women into the 'mainstream of economic activities', bunabét work creates pressures for women to engage in 'illicit' trades such as sex work.

The disciplining discourses described by Tigisti complicate the prevailing assumptions about youth entrepreneurship: for bunabét owners, to be an entrepreneur requires the performance of a specific type of femininity. For Tigisti this involves a negotiation of the boundary between her 'work' (obliging) and 'personal' (self-assured) identities and is also linked to her sense of 'being serious' about her work: By proudly refusing to perform the material aspects of the discursively constructed identities projected on her by her male customers, Tigisti feels able to reassert some control over the space of her coffeehouse.

Male discourses and the behaviours that they render permissible within the space of coffeehouses were widely cited in my interviews as the greatest challenge bunabét women face as entrepreneurs. Only one of the thirty women I spoke to said that she was engaging in sex work, while everyone else described a multitude of strategies they used to parry sexual overtures. While these conceptions of bunabét women are perhaps based on a grain of historical truth, according to my interlocutors, only a small number of bunabét women today engage in prostitution. These discourses are nevertheless powerful in shaping the relations between young women and their male clientele. In a patriarchal context like Ethiopia, despite shifting opportunities, women's labouring bodies are still largely seen as 'out of place' when away from the control of fathers or husbands (Jacobs, Brahic, Olaiya 2015: 402). In such a setting, their discursive categorisation as young women actively services the powerful in society and entrenches their dominance over bunabét women. These disciplining discourses serve to further reinforce young women's relegation to the category 'young woman' because, while working in a coffeehouse, they are unable to get married, which in Ethiopia is an important marker of socially recognised adulthood (Pankhurst 1992).

In contrast to the other young women Tigisti describes, she has persevered in her entrepreneurial pursuit despite challenges. She does so by performing a specific

6 All interviewees have been identified in the text using pseudonyms. 
type of entrepreneurial identity ('being serious' about her work). She situates this identity in contrast to the frivolous youthful femininity that she attributes to most of her competitors (who are going to clubs, leaving their bunabéts with employees, and ultimately forfeiting their freedom through marriage). While she understands her choice to have been more difficult than the prescribed path to marriage ('I could have just lived on what my husband brings home'), the freedom afforded by her decision to start a bunabét seems important to Tigisti's sense of self as a young woman who has lived her whole life in a country that, at least legally, recognises the equal rights of women. Tigisti was born in 1995, the year that the Constitution of the Federal Democratic Republic of Ethiopia was signed; Article 35 of that document, on the 'Rights of Women', guarantees women equal rights to men (FDRE 1995).

Tigisti's story reflects the role of urbanisation in shifting the topography of possibility for young women. Through Tigisti's life herstory, we can see her forceful rejection of the life path prescribed to her by her parents and, specifically, of the norms that she associates with a rural milieu. As Sommers (2010: 318) argues, cities 'provide opportunities for re-invention for many urban youth'. The way Tigisti explained it, her 'entrepreneurial' identity is incongruent with the feminine ideals she associates with women in rural areas and with the types of performances necessary once one becomes a wife and a mother. Yet, it is not as simple as rejecting one identity or discourse in favour of another, because performers in fact 'occupy the norm in myriad ways, exceed the norm, rework the norm', thereby exposing the possibility of transforming reality (Butler 2004: 217). Through this lens, people are recognised for their ability to simultaneously occupy multiple subject positions (i.e. young woman and entrepreneur) (Gregson, Rose 2000), thereby opening up the scope for the slippage, subversion, and disruption of discourses.

\section{Samrawit: 'Forced' to migrate}

I was born in Idaga Hamus [a town north of Wukro in Tigray] in 1996. My father died when I was small, and I was abandoned by my mother. I grew up with my father's mother.

I stopped school at Grade 10 because my grandmother died so my aunt forced me to go to Saudi Arabia. 'You must pay the family back for all you have cost us', she said. I was 17 when I left Ethiopia. I went through an agency in Addis. I was a maid for a family in Riyadh... I stayed with that family for nine months, then I left... Many men in the household, they tried to touch me, so I left. Thanks be to God, I had relatives in Saudi Arabia who helped me find a new job. 
The whole time, I sent money back to my aunt in Ethiopia... When I came back to Ethiopia, I opened a bunabét because it requires very little money.

I love to write poems. I want to be a fashion designer or a writer, but in this job, it is difficult to earn money quickly.

I still give money to my aunt. I must pay her back for raising me when my mother abandoned me, but I try to save too... I do this through daily iqqub payments. ${ }^{7}$ This business [bunabét] is transitional. It helps work as a bridge toward another business. I will open a steam bath. Many people are asking for this service, but they don't have steam baths in Wurko, not even in any of the hotels. $^{8}$

Samrawit's story illustrates the possibilities that have opened up as a result of her entrepreneurial pursuit. According to Samrawit's telling, before she opened a bunabét the circumstances of her life were largely dictated by her aunt. While she continues to pay some of her earnings from the bunabét to this aunt, owning a coffeehouse has allowed Samrawit to save money (through daily iqqub payments) and aspire to larger entrepreneurial activities (opening a steam bath).

One interesting element of Samrawit's story is her migration to Saudi Arabia. According to the International Labour Organisation (2017), Ethiopia is one of the regions with the largest flows of low-skilled, female domestic labour migrants to the Gulf and Middle Eastern countries, and there has been a surge of recent scholarship seeking to explain this trend (e.g. Zewdu 2018). The GoE used to encourage and facilitate labour migration to Saudi Arabia; however, the prevalence of abuse and changing economic and political circumstances in Saudi Arabia have more recently caused concern among Ethiopian policy-makers (RMMS 2014). In Wukro, community members believe that the city's development can be largely attributed to remittances sent back by young people (mostly young women) who have gone to the Middle East. As an older community member explained to me:

All of the buildings you see are built by people who went to Saudi Arabia and then came back or sent money back. The people here are not changing their lives through local employment. There is a lot of unemployment in Wukro.

\footnotetext{
7 lqqubs are informal rotating savings and credit associations. Bunabét owners usually contribute on a daily or weekly basis.

8 All quotes from Samrawit were collected during interviews conducted in her coffeehouse in Wukro on $9,10,17,19$, and 25 July.
} 
It's mostly young people who leave [to Saudi Arabia] because they are unemployed... Girls outnumber boys going to Saudi Arabia. ${ }^{9}$

We can see here the ways in which labour migration is understood to be linked to broader economic issues (i.e. youth unemployment). I was confused by the contradictions in the imaginaries and realities of labour migration to Saudi Arabia among young women in Wukro and surprised at the number of coffeehouse owners who had worked in Saudi Arabia prior to starting their businesses. On the one hand, labour migration was explained by many as one of the only means through which young women could 'get more money', ${ }^{10}$ either for themselves or their families. Yet, on the other hand, my interlocutors (including Samrawit) explained that they had opened a coffeehouse 'because it requires very little money'.11 The majority of people already own the materials with which to conduct the coffee ceremony; so to start a coffeehouse, most young women need only to buy a bag of coffee, some sugar, and some tables and stools. Most often business is conducted in rented rooms, which double as the young women's homes. So why then is it the case that so many coffeehouse owners have been to Saudi Arabia, and yet find themselves in much the same predicament as those who aspire to go abroad to improve their economic situation? The answer might lie in the discursive construction of women as altruistic and virtuous agents of development, which is grounded in the same narratives that underpin the promotion of women's 'empowerment' through entrepreneurship.

In my interviews, three main themes emerged around young women's reasoning for going (or wanting to go) to Saudi Arabia: (1) women feel under pressure from their elders who 'force' them to go (as in Samrawit's case); (2) women feel a sense of duty to support their families (as one woman put it, 'I thought it was better to suffer for a short time for the good of my sisters and my mum. . . to improve their lives ${ }^{\prime 12}$ ); or (3) as an attempt to 'improve their [own] life'.13 While young people, and women are increasingly being portrayed as migrants in their own right (van Blerk 2008), there is also growing appreciation for the role that families and households play in the decision to migrate (Fleischer 2007). The experiences and perceptions of migration among bunabét owners in Wukro suggest that migration cannot be understood

\footnotetext{
9 Interview with a 33-year-old woman, conducted in her home in Wukro on 17 July 2018.

10 Interview with a 22-year-old bunabét owner, conducted in her coffeehouse in Wukro on 9 July 2018.

11 Interview with a 23-year-old bunabét owner, conducted in her coffeehouse in Wukro on 26 July 2018.

12 Interview with a bunabét owner, conducted in her coffeehouse in Wukro on 9 August 2018.

13 Interview with a 41-year-old woman, conducted in her home in Wukro on 6 July 2018.
} 
simply as a path to independence (Yaqub 2009). Rather this analysis indicates that youth transitions through migration are better conceptualised as 'negotiated and constrained interdependencies' across generations (Punch 2015: 263).

When I asked a man in the Industry and Business Office of the Wukro City Administration why there were so many returnees from Saudi Arabia running coffeehouses in Wukro, he responded:

Most of the money goes to their family and the women only keep a small amount of money. Everyone is asking the women who go abroad for money, and women are kind of meek, so they give everyone money and are left with very little. ${ }^{14}$

While 'meekness' is perhaps incongruent with the image of an 'empowered' woman, the narrative the man is sharing here is that women are inclined to distribute their earnings amongst their families and/or communities - whether out of selflessness or spinelessness. Interviewees understood this generosity to be unique to women, in contrast to men.

Lots of people are emigrating to Saudi Arabia and some (the good ones) send remittances. When [men] come back [from the Middle East], they waste their money. They just build houses and then spend the rest on drinking and many wives. $^{15}$

On the surface, Samrawit appears to fit these narratives: she went abroad and faithfully sent money back to support her family, and as a result, she returned to Ethiopia without enough money to make many improvements in her own socioeconomic positioning. However, in hearing Samrawit's own interpretation of these events, it is clear that she does not always reliably reproduce discourses around female responsibility, dependability, or feebleness. My point is that, for Samrawit, migration to Saudi Arabia was not a choice made out of some self-sacrificing desire to lift her family out of poverty or to develop her community, rather it was one made based on a position in which she perceived herself to be constrained: to have no other choice but to accede to her aunt's request, given that she is a as a young woman existing within a social regime in which this label implies deference. Since

\footnotetext{
14 Interview with an Industry and Business Officer at the Wukro City Administration on 7 August 2018.

15 Interview with Kahasa, conducted in her coffeehouse in Wukro on 19 July 2018.
} 
opening the coffeehouse, however, the implication, in Samrawit's telling, is that her relationship with her aunt has shifted. While she continues to send a portion of her earnings to the family, she also manages to save some for herself. This allows her to work towards personal goals, independent of her family. 'Promoting savings' is a key goal of the government's MSE Development Policy and Strategy (FDRE-MoUDH 2012: 21).

\section{Kahasa: Work fit only for young women}

I was born near Wukro [in 1991].

I got pregnant when I was in Grade 9. While I was pregnant my husband was very kind and caring. He stopped with his addictions [alcohol and khat, a mild stimulant], but once the baby was born, he went back to his old ways... I wasn't happy, so the relationship ended. I left with only a few clothes and my daughter.

I got a loan from the government to open a bunabét.

If you open a bunabét, people think that you don't have any dreams. You are not respected. Everyone - both old and young, both those who are better than you and those who aren't - they look down on you.

[In this job] you have to be careful about how you look and present yourself. You can make a lot [of profit] by wearing short skirts, sitting with your [male] customers, drinking with them, letting them hug you, but the costs outweigh the benefits. Sometimes I do these things just to get money from people, but I don't want my daughter to see me do that... Once I heard her say to her friend '[My mother] is working until eleven at night sometimes, and there are all kinds of men coming, hugging, and kissing her. She only does it because she wants their money. I don't feel good about my mother's work. I wish she would just stay at home, prepare me food, and take care of me.' That made me feel very ashamed.

[When men proposition me] I always laugh and twist it around; I try to switch the direction of the conversation. I am always nice about it, so I don't have a problem. If you are not polite then the men might hit you. Sometimes if you say 'no' [to their sexual advances], they don't come back, but if you're nice, many do. 
Right now, business is not good. I don't have many customers. Men are only drinking coffee at the bunabéts owned by beautiful women. ${ }^{16}$

Kahasa's story can tell us something about the dynamism of what it means to be a young woman in this context. For many with whom I spoke, having a child was understood as a key marker of adulthood; in Ethiopia, child-rearing is revered, and female social recognition is often gained through motherhood (and marriage) (Pankhurst 1992). Yet, despite being a mother and divorced, ${ }_{17}^{7}$ Kahasa's experience was not so different from other coffeehouse owners with whom I spoke. In the bunabét, Kahasa's social status was tied to a youth identity, even though as a mother, she had already made the transition out of this social category. However, it was also based on her categorisation as a young woman that Kahasa was able to make certain claims, including the ability to get a loan from the government to start her business.

Entrepreneurship through MSEs is being proposed by the GoE as a tool for reducing unemployment among young women, particularly in urban areas, and bunabéts have become a low-barrier entrepreneurial employment option for those codified as young women. Despite being an accessible option, bunabéts are not considered desirable work, as Kahasa's quote indicates. My questions to young women about why young men cannot run bunabéts were always met with a laugh. In Tigray, the coffee ceremony performed in these coffeehouses is central to people's sense of pride in their tradition of 'Ethiopian hospitality', and performing the ceremony serves to 'reinforce a culturally sanctioned womanhood' (Mjaaland 2004: 71). By doing it well, women can gain a reputation for generosity and hospitality and for possessing the feminised characteristics of skill and hard work.

In Ethiopia's development discourse, entrepreneurship is promoted as a collectivist initiative through which young women can contribute to national growth (Di Nunzio 2015). This is precisely the feminisation of policy that Roy (2010: 70) describes as the 'ways in which development operates through women-oriented policies that in turn serve to maintain traditional gender roles of social reproduction'. While the government loan allowed Kahasa to become a so-called 'entrepreneur', it was only possible through specifically feminised forms of work.

Kahasa's comments reveal the ways in which women's work in the space of coffeehouses is discursively devalued and delegitimised, in part by labelling it work only suitable for young women. Women's subordination in the space of coffeehouses

16 All quotes from Kahasa were collected during interviews conducted in her coffeehouse in Wukro on 19 July and 9, 15, and 21 August.

17 In Wukro, marriage and divorce are more culturally than legally defined. As has been noted by anthropologists, marriage 'is more of a process than an event, played out in multiple stages of betrothal and divorce' (Weis 2014: 11). 
could thus be understood as a form of 'symbolic violence that denies women's legitimacy even as it bespeaks these young men's own subjugation' (Weiss 2009: 85). Furthermore, even from the supposedly 'empowered' position of being a smallbusiness owner, Kahasa is subjected to discourses around her supposed sexual promiscuity, which serve to discipline her in both symbolic and material ways. As Roy (2003) further argues, feminised forms of work serve to perpetuate women's vulnerable status. Kahasa's codification as a young woman in particular, exacerbates this vulnerability.

As Kahasa (and others) explained, young women understand their success in the coffeehouse business to be linked to their physical appearance. Because young men make up the majority of the clientele in Wukro's bunabéts, coffeehouse work requires women to present themselves in a way that attracts (male) customers. It also means that male customers are able to define and regulate the types of performances that are acceptable within these spaces. Women who do not conform to these norms are at risk of violence and of losing their customer base, as Kahasa explained.

For the most part, women in Wukro's coffeehouses pay a lot of attention to their appearance. It is not uncommon for these women to wear elaborately decorated gowns or Tigrayan dresses. Others choose shirts splashed with English slogans, trousers or leggings, and stylish sneakers. Some women wear extremely tight or revealing clothes, which are met with raised eyebrows from others (particularly women) in the community, despite the fact that this 'sexy' attire is never worn outside of the coffeehouse itself. Much like the sex workers described by van Blerk (2011: 225), these women

tailor the way they dress to meet the desires of their audience at any given time through using and counteracting dominant discourse related to gendered identities for securing work. Sometimes this requires them to adhere to dominant discourse surrounding what it means to be an (often rural) Ethiopian woman and other times engaging in slippage from the norms and values of that role.

While Kahasa evidently puts a lot of time and effort into her appearance - wearing beautiful clothes, getting her hair done, applying makeup - she tactically capitalises on her femininity, without slipping beyond what she understands to be the bounds of acceptable behaviour for a young woman. However, the boundary here is blurry, and Kahasa herself admits to sometimes doing things 'just to get money from people' (namely engaging in flirtatious behaviour). In our conversations, Kahasa expressed her desire to keep these behaviours hidden from her young daughter, who she knows feels ashamed of her mother's relationships with male customers. This reveals the 
way that women such as Kahasa are able to 'separate their work identities from other identities through different performative acts within and outside' the social space of coffeehouses (van Blerk 2011: 225). However, the proximity of their home and work worlds (since the business is carried out in their homes), and the resultant blurring of the public/private boundary increases the challenges associated with separating home and work identities.

\section{Conclusion}

Within much of mainstream development, young women have become the posterchildren of inclusive, sustainable growth. In Ethiopia, and around the world, entrepreneurship is one path that has been promoted as a means through which young women can contribute to poverty reduction, employment creation, and the overall 'progress' of their countries, communities, and families. This instrumental use of women's empowerment is what Roy (2010) would call the 'feminisation of policy'. Interestingly, however, even as the GoE promotes entrepreneurship along these lines, there is a simultaneous lamentation regarding young women's relegation to the informal sector. This is somewhat ironic given that most of the entrepreneurial pursuits undertaken by young women are 'informal' in that they are generally insecure and often unregulated. As the stories of these three women illustrate, these contradictory representations manifest themselves in the instrumental ways women's work is used by patriarchal powers to place the responsibility of development on young women's shoulders or to downplay the legitimacy of their entrepreneurial pursuits when they are not conducive with society's feminine ideals (Cornwall, Anyidoho 2010).

Using entrepreneurship in Wukro's bunabéts as a case study - one mechanism of development that has in recent years gained predominance in mainstream approaches - I have demonstrated the ways that multiple ambivalences are playing out in the lives of young female entrepreneurs in Wukro. There are some ways in which the young women's stories presented here fit within the narratives put forth by the GoE and other development actors regarding the important role women could or should play in economic and social 'development'. These discourses tend to focus on the possibilities created for young women through entrepreneurship but often fail to consider the different constraints experienced by women who become business owners. For Tigisti, Samrawit, and Kahasa, opening a bunabét allowed them to gain some level of 'independence', to 'escape' from situations in which they felt constrained, and to search for meaning and mould new types of identities. Yet in other ways these stories challenge assumptions implied in these discourses. As these stories reveal, the way people in Wukro talk about bunabét owners, and the way bunabét owners talk about themselves, do not portray women as 'empowered' nation-builders. Because 
of the feminisation of bunabét work, in order to be an entrepreneur in this context women must perform a specific type of femininity, one that tactfully capitalises on their sexuality. Owning a bunabét also makes women vulnerable to sexual advances and violence inflicted on them by their male clientele.

This article adds to the growing body of feminist literature on girls and women in development by challenging narrow and essentialised depictions of young women, complicating simplistic narratives about empowerment through entrepreneurship, and highlighting the instrumentality of mainstream approaches to engaging women in development. Given the important role that has been thrust upon women by the development establishment, it is time they become more than silent targets of policy decisions made by men much older than themselves. Without taking the stories of young women into consideration throughout the policy-making process, development schemes will continue failing to account for the structural and sociocultural challenges unique to the women engaging with these programmes. Only through the inclusion of young women's accounts will we be able to work towards truly transformative and emancipatory development.

As my focus is geographically and situationally limited, further research is necessary to understand the extent to which the experiences described by my interlocutors hold true across the region, across the country, and across other industries. In Wukro, bunabéts constitute one of the main MSEs owned and operated by young women, but to make more robust claims about young women entrepreneurs broadly, it is crucial that further research investigate whether similar dynamics are playing out in the lives of young women entrepreneurs in other settings. Finally, it is important to acknowledge that, although young women's subjective experiences deserve to be considered by policy-makers, I do not mean to suggest that these narratives are enough to design effective development policy or programming. Rather, I am arguing that research at the level of individual perception and understanding is an important, and often overlooked, piece of a much larger development puzzle.

While development has indeed created new possibilities for young women, it has also made them subject to different disciplining discourses. In part because it is only through feminised forms of labour that women are able to undertake entrepreneurial pursuits, engaging in these businesses can serve to reinforce rather than break down existing gender and generational hierarchies. Understanding the ways women like them think about themselves - their circumstances, their societies, their relationships, their horizons, in all their complexity and diversity - is key to promoting inclusive and transformative development. 


\section{References}

Aling'o, P., Abdulmelik, N. 2017. From Rhetoric to Action: Delivering for Young Women in Africa. African Governance Architecture Policy Brief 100. Pretoria, SA: Institute for Security Studies.

Anyidoho, N. A., Kayuni, H., Ndungu, J., Leavy, J., Sall, M., Tadele, G., Sumberg, J. 2012. Young People and Policy Narratives in Sub-Saharan Africa. FAC Working Paper 032. Sussex: Future Agricultures Consortium.

AUC (African Union Commission). 2006. African Youth Charter. African Union Youth Division. Banjul: African Union.

Ayele, S., Khan, S., Sumberg, J. 2017. 'Introduction: New Perspectives on Africa's Youth Employment Challenge.' IDS Bulletin: Transforming Development Knowledge, Vol. 48, No. 3: 1-12.

Balsvik, R. R. 1998. 'Student Protest, University and State in Africa.' Forum for Development Studies, Vol. 25, No. 2: 301-325.

Bhopal, K. 2010. 'Gender, Identity and Experience: Researching Marginalised Groups.' Women's Studies International Forum, Vol. 33, No. 3: 188-195.

Broussard, N. H., Tekleselassie, T. G. 2012. Youth Unemployment: Ethiopia Country Study. International Growth Centre Working Paper 12/0592. London: London School of Economics and Political Science.

Burgess, G. T., Burton, A. 2010. 'Introduction.' Pp. 9-32 in Burton, A., Charton-Bigot, H. (eds). Generations Past: Youth in East African History. Athens, OH: Ohio University Press.

Butler. 2004. Undoing Gender. London: Routledge.

Camfield, L., Tafere, Y. 2011. 'Community Understandings of Childhood Transitions in Ethiopia: Different for Girls?' Children's Geographies, Vol. 9, No. 2: 247-262.

Campbell, R., Wasco, S. M. 2000. 'Feminist Approaches to Social Science: Epistemological and Methodological Tenets.' American Journal of Community Psychology, Vol. 28, No. 6: 773-791.

Chigunta, F., Schnurr, J., James-Wilson, D., Torres, V. 2005. 'Being "Real" About Youth Entrepreneurship in Eastern and Southern Africa: Implications for Adults, Institutions, and Sector Structures.' SEED Working Paper No. 72. Geneva: International Labour Office.

Cornwall, A., Anyidoho, N. A. 2010. 'Introduction: Women's Empowerment: Contentions and Contestations.' Development, Vol. 53, No. 2: 144-149.

Cornwall, A. 2007. 'Buzzwords and Fuzzwords: Deconstructing Development Discourse.' Development in Practice, Vol. 17, No. 4-5: 471-484.

Cornwall, A. 2016. 'Women's Empowerment: What Works?' Journal of International Development, Vol. 28, No. 3: 342-359.

Cornwall, A., Harrison, E., Whitehead, A. 2008 'Gender Myths and Feminist Fables: The Struggle for Interpretive Power in Gender and Development.' Pp. 1-19 in Cornwall, A., Harrison, E. Whitehead, A. (eds). Gender Myths and Feminist Fables. Malden, MA: Blackwell Publishing.

Devault, M. L. 1990. 'Talking and Listening from Women's Standpoint: Feminist Strategies for Interviewing and Analysis.' Social Problems, Vol. 37, No. 1: 96-116. 
Di Nunzio, M. 2015. 'What Is the Alternative? Youth, Entrepreneurship and the Developmental State in Urban Ethiopia.' Development and Change, Vol. 46, No. 5: 1179-1200.

Edwards, R. 1998. 'A Critical Examination of the Use of Interpreters in the Qualitative Research Process.' Journal of Ethnic and Migration Studies, Vol. 24, No. 1: 197-208. Enria, L. 2018. The Politics of Work in a Post-Conflict State: Youth, Labour \& Violence in Sierra Leone. Oxford: James Currey.

Etherington, K. 2006. 'Understanding Drug Misuse and Changing Identities: A Life Story Approach.' Drugs: Education, Prevention and Policy, Vol. 13, No. 3: 233-245.

FDRE (Federal Democratic Republic of Ethiopia). 1995. Constitution of the Federal Democratic Republic of Ethiopia. Addis Ababa: Government of Ethiopia.

FDRE-MoLSA (Ministry of Labour and Social Affairs). 2009. National Employment Policy and Strategy of Ethiopia. Addis Ababa: Government of Ethiopia.

FDRE-MoUDH (Ministry of Urban Development and Housing). 2012. Micro and Small Enterprise Development Policy \& Strategy. Addis Ababa: Government of Ethiopia.

FDRE-MoWCA (Ministry of Women and Children Affairs). 1998. Implementing the Ethiopian National Policy for Women: Institutional and Regulatory Issues. Washington, DC: World Bank Publications.

FDRE-MoYSC (Ministry of Youth, Sport, and Culture). 2004. National Youth Policy. Addis Ababa: Government of Ethiopia.

Fleischer, A. 2007. 'Family, Obligations, and Migration: The Role of Kinship in Cameroon.' Demographic Research, Vol. 16: 413-440.

Gebre-Egziabher, T., Yemeru, E. A. 2019. 'Urbanization and Industrial Development in Ethiopia.' Pp. 785-803 in Cheru, F., Cramer, C., Oqubay, A. (eds). The Oxford Handbook of the Ethiopian Economy. Oxford: Oxford University Press.

Gebremariam, F. M. 2017. 'Factors Affecting the Growth of Women- Operated Micro and Small Enterprises (MSEs) in Ethiopia.' Üniversitepark Bülten, Vol. 6, No. 1: 56-66.

Glaser, B. G., Strauss, A. L. 1967. The Discovery of Grounded Theory: Strategies for Qualitative Research. Chicago, IL: Aldine Publishing.

Gregson, N., Rose, G. 2000. 'Taking Butler Elsewhere: Performativities, Spatialities and Subjectivities.' Environment and Planning D: Society and Space, Vol. 18, No. 4: 433-452. Hanson, S. 2009. 'Changing Places Through Women's Entrepreneurship.' Economic Geography, Vol. 85, No. 3: 245-267.

Helgren, J., Vasconcellos, C. A. 2010 'Introduction.' Pp. 1-13 in Helgren, J., Vasconcellos, C. A. (eds). Girlhood: A Global History. New Brunswick, NJ: Rutgers University Press.

Hoppe, K. 1993. 'Whose Life Is It, Anyway?: Issues of Representation in Life Narrative Texts of African Women.' The International Journal of African Historical Studies, Vol. 26, No. 3: 623-636.

International Labour Organization. 2017. Promote Effective Labour Migration Governance in Ethiopia. ILO Program Achievements Report. Geneva: International Labour Office. Jacobs, S., Brahic, B., Olaiya, M. M. 2015. 'Sexual Harassment in an East African Agribusiness Supply Chain.' The Economic and Labour Relations Review, Vol. 26, No. 3: 393-410. 
Kirk, J., Mitchell, C., Reid-Walsh, J. 2010 'Toward Political Agency for Girls: Mapping the Discourses of Girls Globally.' Pp. 14-30 in Helgren, J., Vasconcellos, C. A. (eds). Girlhood: A Global History. New Brunswick, NJ: Rutgers University Press.

McRobbie, A. 2009. The Aftermath of Feminism: Gender, Culture and Social Change. London: SAGE.

Mengistu, M. M. 2017. 'Early Marriage in Ethiopia: So Little Done But So Much to Do.' International Journal of Information, Business and Management, Vol. 9, No. 3: 102-114.

Mjaaland, T. 2004. 'Beyond the Coffee Ceremony: Women's Agency in Western Tigray, Northern Ethiopia.' Pp. 71-77 in Lillebø, K., Kennedy, A. L., Smørvik, K. H., Stensrud, A. B., Linderud, H. T. (eds). Arboksredaksjonen in Betwixt and Between Sosialantropologistudentenes årbok. Oslo: University of Oslo.

Moeller, K. 2014. 'Searching for Adolescent Girls in Brazil: The Transnational Politics of Poverty in "The Girl Effect".' Feminist Studies, Vol. 40, No. 3: 575-601.

Oya, C. 2019. 'Federalism in Ethiopia's Transformation.' Pp. 669-685, in Cheru, F., Cramer, C., Oqubay, A. The Oxford Handbook of the Ethiopian Economy. Oxford: Oxford University Press.

Pankhurst, H. 1992. Gender, Development and Identity: An Ethiopian Study. London: Zed Books.

Peacock, J. L., Holland, D. C. 1993. 'The Narrated Self: Life Stories in Process.' Ethos, Vol. 21, No. 4: 367-383.

Punch, S. 2015. 'Youth Transitions and Migration: Negotiated and Constrained Interdependencies Within and Across Generations.' Journal of Youth Studies, Vol. 18, No. 2: 262-276.

Rekiso, Z. S. 2019. 'Urbanization and Industrial Development in Ethiopia.' Pp. 428-446 in Cheru, F., Cramer, C., Oqubay, A. The Oxford Handbook of the Ethiopian Economy. Oxford, UK: Oxford University Press.

RMMS (Regional Mixed Method Secratariat). 2014. The Letter of the Law: Regular and Irregular Migration in Saudi Arabia in a Context of Rapid Change. Mixed Migration Research Series 4. Nairobi: Regional Mixed Migration Secretariat.

Roy, A. 2010. Poverty Capital: Microfinance and the Making of Development. London, UK: Taylor \& Francis Group.

Roy, A. 2003. In City Requiem, Calcutta: Gender and the Politics of Poverty. Minneapolis, MN: University of Minnesota Press.

Shain, F. 2012. "“The Girl Effect": Exploring Narratives of Gendered Impacts and Opportunities in Neoliberal Development.' Sociological Research Online, Vol. 18, No. 2: 181-191.

Sommers, M. 2010. 'Urban Youth in Africa.' Environment and Urbanization, Vol. 22, No. 2: 317-332.

Switzer, H. 2013. '(Post)Feminist Development Fables: The Girl Effect and the Production of Sexual Subjects.' Feminist Theory, Vol. 14, No. 3: 345-360.

Utas, M. 2005. 'Victimcy, Girlfriending, Soldiering: Tactic Agency in a Young Woman's Social Navigation of the Liberian War Zone.' Anthropological Quarterly, Vol. 78, No. 2: 403-430. 


\section{NV STATI / ARTICLES}

van Blerk, L. 2008. 'Poverty, Migration and Sex Work: Youth Transitions in Ethiopia.' Area, Vol. 40, No. 2: 245-253.

van Blerk, L. 2011. 'Negotiating Boundaries: The Sex Work Identities of "Bar Girls" in Nazareth, Ethiopia.' Gender, Place \& Culture, Vol. 18, No. 2: 217-233.

van Stapele, N. 2014. 'Intersubjectivity, Self-Reflexivity and Agency: Narrating About "Self" and "Other" in Feminist Research.' Women's Studies International Forum, Vol. 43, No. March: 13-21.

Waller, R. 2006. 'Rebellious Youth in Colonial Africa.' The Journal of African History, Vol. 47, No. 1: 77-92.

Weis, J. R. 2014. Socio-Economic Trends and the Rising Age of Marriage Among Women in the Developing World: Implications for Policy and Advocacy. Gendered Perspectives on International Development Working Paper 305. Ann Arbor, MI: University of Michigan.

Weiss, B. 2009. Street Dreams and Hip Hop Barbershops: Global Fantasy in Urban Tanzania. Bloomington, IN: Indiana University Press.

World Bank. 2008. The World Bank Launches Private-Public Initiative to Empower Adolescent Girls. [press release]. Washington, DC: The World Bank. [cit. 11/2/2020] Available from: http://siteresources.worldbank.org/INTECAREGTOPGENDER/Resources/ AdolescentGirls08PressRelease1.pdf.

Yaqub, S. 2009. Independent Child Migrants in Developing Countries: Unexplored Links in Migration and Development. Innocenti Working Paper IWP-2009-01. Florence: UNICEF Innocenti Research Centre.

Zewdu, G. A. 2018. 'Ethiopian Female Domestic Labour Migration to the Middle East:

Patterns, Trends, and Drivers.' African and Black Diaspora: An International Journal, Vol. 11, No. 1: 6-19.

@BY-NC Zoë Johnson, 2020.

(ब) BY-NC Institute of Sociology of the Czech Academy of Sciences, 2020.

Zoë Johnson is a recent graduate from the MPhil in Development Studies at Oxford's Department of International Development. She now works as the Donor Tracker policy and is an editorial associate at SEEK Development in Berlin. Contact email: zoe.jo@icloud.com. 